\title{
Strategies for the Valorisation of Chestnut Resources in Italian Mountainous Areas from a Sustainable Development Perspective
}

\author{
Stefano Bruzzese ${ }^{(D)}$, Simone Blanc * $*$ and Filippo Brun $(\mathbb{D}$ \\ Department of Agricultural, Forest and Food Sciences (DISAFA), University of Torino, Largo Paolo Braccini 2, \\ 10095 Grugliasco, Italy; stefano.bruzzese@unito.it (S.B.); filippo.brun@unito.it (F.B.) \\ * Correspondence: simone.blanc@unito.it; Tel.: +39-011-670-8684
}

Received: 24 April 2020; Accepted: 20 May 2020; Published: 23 May 2020

check for updates

\begin{abstract}
The chestnut tree has characterised the social history of the Italian hills and mountains. However, in recent years, this resource has been abandoned because of the change in socio-economic needs. The aim of this study is twofold: (i) To give an overview of this resource, assessing the strengths-weaknesses-opportunities-threats of the chestnut tree through the use of the SWOT methodology; (ii) to provide action strategies for resource valorisation, in accordance with the SDGs set out in the UN 2030 Agenda, by using the TOWS methodology. Our results suggest four strategies, specifically; 'resource-based', 'network-based', 'policy-based' and 'market-based', capable of valorising the resource from environmental, economic and societal points of view. The active management of chestnut forests, together with the development of a value chain can guarantee sustainable production, technological and process innovation and could empower companies to face global markets in a more competitive way and lead to the creation of high value-added products, generating a strong economic and social engine for the revival of the sector. Moreover, the commitment of the private sector to the reorganisation of the supply chain must also be accompanied by coherent public policy action. This is essential for the adoption of plans and programmes consistent with sustainable development objectives, ensuring their prioritisation and implementation.
\end{abstract}

Keywords: chestnut; public policy; valorisation; SDGs; SWOT; TOWS

\section{Introduction}

The long-established and widespread problem of deforestation on a global scale eclipses the little-known negative impact of poor forest management, even in some of the world's most developed temperate areas. In fact, in relation to their potential, $21 \%$ of the world's forests are currently either not managed or are underexploited [1]. The reasons are mainly linked to economic aspects, given that frequently the high costs of forest management, the lack of connections between inland and mountainous areas to economic centres, the post-recession collapse of the lumber market for the construction sector [2] and the lack of public funding do not guarantee satisfactory economic returns for businesses and forestry enterprises [3].

In addition to economic reasons, it should be remembered that forest management is also intrinsically linked to other key sustainability issues, such as social and environmental aspects. In some fragile areas, such as mountain areas, the lack of active forest management can undermine the stability of wooded slopes, causing problems of hydrogeological instability and threatening the liveability of populated areas [4]. In particular, the management of forests in mountain areas has decreased in recent years, due to the difficult orographic conditions, the inadequate road networks, the high cost 
of labour and the development of urban industrialisation, making forestry activities economically unattractive [5]. These phenomena have also been accompanied by a social transformation and, with the tertiarisation of the economy, the lumberjack has become an employment with a low social profile [6]. Forestry companies, thus have to cope, not only with the changing needs of the timber industry and the interests of forest owners, but also with an increasingly hostile public opinion towards them [7].

The European mountains have an extension of almost 1.9 million $\mathrm{km}^{2}$ and about $19 \%$ of the population lives in a mountain context [8]. An emblematic case in Europe is the sweet chestnut tree (Castanea sativa Mill.), a species covering over 2.5 million hectares, approximately $89 \%$ of which is concentrated in the mountainous areas of a handful of countries (France, Italy, Spain, Portugal and Switzerland) [9]. In Italy this species is widespread throughout the Alps and the Apennines, occupying almost 800,000 hectares, specifically in the submontane areas (500-1000 m above sea level) [10,11]. The surface of chestnut trees at national level is almost all characterised by coppice forests, only a small part, about 66,000 hectares, is made up of high forest stands.

The chestnut tree has significantly characterised the development of Italian mountainous areas, creating the so-called 'civilisation of the chestnut tree' [12,13], which arose a few centuries after the introduction of the species (in the first century CE) by the Romans, and experienced a period of abandonment after World War II, due to changing social needs [14]. It corresponded to the massive use of the chestnut tree for multiple purposes, including human and domestic animal nutrition, giving rise to entire civilizations around this resource.

In the past, the elasticity of the species and its capability to provide several products (fruit, timber and fire wood) triggered its diffusion in many mountainous areas, contributing, in addition, to the provision of several environmental services still relevant today, such as water regulation, protection of the territory, landscaping, recreational activities, among others [10].

Given the abandonment over the last 70 years, today the Italian chestnut forests are old coppices with a mostly monospecific and monoplane structure. Of these woods, $36 \%$ have aged beyond the normal cultivation cycle or have been abandoned and are frequently affected by pests or diseases [10].

Another cause of the poor management of this widespread resource, which contains a large amount of standing timber, is the ownership regime and the consequent fragmentation and dispersion of land units [15]. In fact, approximately $70 \%$ of chestnut wooded zones belong to private individuals who have not carried out any form of forest management since the Second World War. The remainder are publicly owned, with larger dimensions but generally with lower quality woods [16].

Another aspect concerns orography. In fact, the difficult practicability, the frequently steep slopes and the rugged terrain, constitute a significant obstacle to the management of these mountain forests [17]. This context is worsened by the lack of infrastructure, since more than three-quarters of the chestnut stands have an insufficient network of roads and forest tracks. As a result, the costs of forestry management increase, and income from forests is reduced, often with negative stumpage values [18].

The combination of all these unfavourable conditions determines that only $3 \%$ of the available sweet chestnut resources are harvested, making Italy one of the lowest-ranking European countries in terms of the ratio between timber felling and regeneration $[19,20]$.

From a political point of view, at European level, there is no common direction for promoting forest management, although a European framework for forestry actions (COM 659 of 2013) exists, ensuring that European forests are managed in a sustainable way. Additionally, other EU initiatives influence forests, such as the CAP (community agricultural policy) and the ERDF (European Regional Development Fund). However, forest legislation varies from country to country within Europe.

In Italy, forest management is regulated at a regional level, but the legal matter of forests is intricate, since no single national institution coordinates the sectorial policies. In addition, national and regional competences overlap in many areas. For instance, although the national 'Ministry of Agriculture, Food and Forestry Policies' retains competence on patrimonial aspects and guidance and 
coordination on ordinary management, the "Ministry of the Environment and Protection of Land and Sea" deals with naturalistic constraints, and in addition, the 'Ministry for Cultural Heritage and Activities and Tourism' is responsible for the landscape [21]. Moreover, although a recent national framework law on 'forests and forest supply chains' (Decree Law No. 34 of 18th April 2018) has been set out, the primary competence, as dictated by the Italian Constitution, lies with the autonomous regions and provinces, leaving them the power to decide whether to adopt the national law or their own regional law [22,23] and contributes to create an even more complex framework of competences in the context of forest management.

Nevertheless, forests are a significant part of the environment, the protection of which is exclusive competence of the state. So, although environmental legislation is equally valid throughout the country, following the transposition of European directives, this often comes into conflict with regional forestry legislation.

Lastly, the 'Ministry of Labour and Social Policies' is in charge of social matters and its main actions are aimed at labour policy and protection, increase in employment and adequacy of the social security system, according to national legislation. In this framework, all forms of social policy and resource use must be developed in accordance with the Sustainable Development Goals (SDGs), which are the 17 goals included in the United Nation's 2030 Agenda, aiming to address current global challenges, such as poverty, inequality, climate change and environmental degradation and which are therefore essential for the development of any future actions [24].

In this context, the present paper aims: (i) To give an overview of the sweet chestnut tree resource, assessing the strengths-weaknesses-opportunities-threats, by means of the use of the SWOT methodology; (ii) to provide action strategies for resource valorisation in accordance with the SDGs of the UN 2030 Agenda, by using the TOWS methodology (Threats, Opportunities, Weaknesses, Strengths) [25].

This article is divided as follows: this introductory Section 1, describes and frames, at different spatial scales, the chestnut tree and the forest and environmental policies involved. Section 2 presents the different strategic planning tools used to assess the chestnut tree, i.e., SWOT and TOWS analyses. Finally, Sections 3 and 4 reports the results obtained by the instruments and discuss the practical problems, challenges and opportunities for the valorisation of the chestnut tree in decision-making processes.

\section{Materials and Methods}

\subsection{SWOT Analysis}

Our reflection on the strategic development of the chestnut tree resource begins by using the consolidated SWOT methodology, similar to numerous works in literature [26-30]. As is common knowledge, SWOT analysis is a tool developed to support decision-making processes [31], while analysing the resource's internal strengths and weaknesses and the opportunities and threats from the external environment [32].

In the context of this study, the SWOT analysis was driven by the three components of sustainability, considering the environmental, societal and economic impacts related to the use and management of the chestnut tree resource, also highlighting their interrelationships. Subsequently, the results were collected in a matrix and graphically represented using Venn diagrams (Figure 1).

Each diagram represents one component of the SWOT matrix, and is composed of three sets, one for each sustainability component. The impacts have been studied both individually ('ONLY Environmental Impacts'; 'ONLY Economic Impacts'; 'ONLY Social Impacts'), in pairs ('Environmental Impacts' AND 'Economic Impacts'; 'Environmental Impacts' AND ‘Social Impacts'; 'Economic Impacts' AND 'Social Impacts') and grouped together ('Environmental Impacts' AND 'Economic Impacts' AND 'Social Impacts'). 


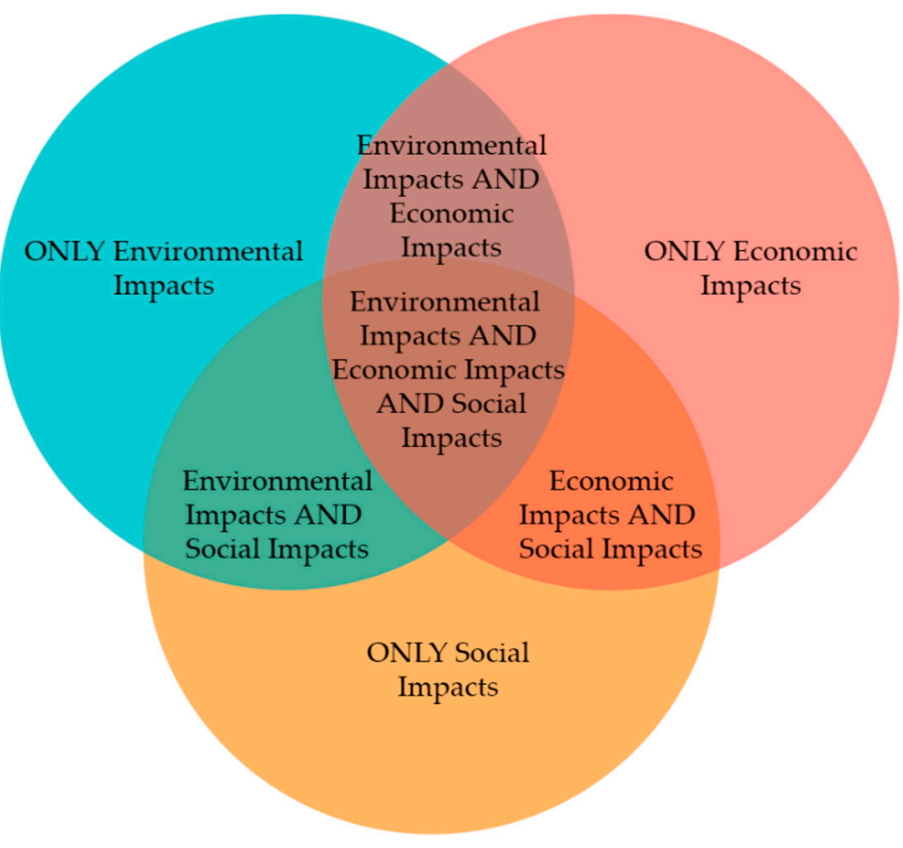

Figure 1. Framework of SWOT analysis of three components of sustainability.

\subsection{TOWS Analysis}

The results of the SWOT matrix are integrated in a TOWS matrix, used to develop strategies that result in a good balance between internal and external factors [33,34]. On an operative level, the main difference between TOWS and SWOT is that TOWS focuses on the external environment, while SWOT emphasises the internal one [30].

The TOWS matrix aims to maximise strengths and opportunities and minimise weaknesses and threats, overcoming the intrinsic limits of the SWOT analysis [35]. Moreover, it is a technique that allows to hypothesise useful actions to improve the current position, considering both positive and negative aspects through a scheme that is easy to understand.

In greater detail, the TOWS matrix proposed by Weihrich [36] identifies four groups of alternative strategies that can be defined as follows:

- $\quad$ SO strategy (Max-Max), which aims to maximise opportunities and strengths, hereinafter referred to as 'resource-based';

- ST strategy (Max-Min), which avoids or minimises threats by emphasising strengths, hereinafter referred to as 'policy-based';

- WO strategy (Min-Max), which decreases weaknesses by maximising opportunities, hereinafter referred to as 'network-based';

- WT strategy (Min-Min) that is focused on minimising both threats and weaknesses, reducing threats and overcoming weaknesses, hereinafter referred to as 'market-based'.

Successively, the strategies identified by the TOWS analysis were also discussed according to the SDGs [24].

\section{Results and Discussion}

\subsection{SWOT Analysis}

The parameters explored in the SWOT analysis have been divided into two general categories: internal and external factors [37]. Among the internal factors, the strengths are the benefits over which one has direct control and which have a positive impact, such as an optimal availability of the chestnut tree resource and its active management. On the other hand, weaknesses are the factors and elements 
that represent an obstacle to the enhancement and creation of a value chain of the species. Among the external factors, opportunities represent potential benefits, while threats correspond to potential obstacles and problems that may or could in the future prevent the valorisation of the resource.

\subsubsection{Internal Factors}

\section{Strengths}

In line with Mariotti et al. [14], the strengths of the chestnut tree resource are linked to its optimal availability. In fact, this species represents $8 \%$ of the national wooded area; other positive points are the strong production potential (average production of chestnut forests managed by coppice is from 6 to $12 \mathrm{~m}^{3} \cdot \mathrm{ha}^{-1} \cdot \mathrm{year}^{-1}$ ) [17], the high reproduction ability, a condition that remains high over time, thus not affected by the age of chestnut stands, and finally the versatility of chestnut tree uses. Its wood is appreciated by the market [15], given its high natural durability (class 2, EN 350), which makes it suitable for the majority of uses without having to resort to treatments; the timber also has good mechanical resistance and good static and dimensional efficiency and possesses an aesthetically pleasing grain for the production of rustic objects and furniture. Moreover, at national level, there is a consolidated tradition of the use of chestnut products by the timber sector companies, as also stated by Pezzi et al. [38].

Furthermore, the civil society has good knowledge of the uses and capabilities of the sweet chestnut tree [10]. In fact it is able to provide timber for structural uses (poles, staves, roundwood), firewood, chemical products (tannin), an edible seasonal fruit and several ecosystem services, such the protection against natural hazards, water regulation, cultural services as for instance recreational and educational activities, given the good presence of secular trees and the storage of $\mathrm{CO}_{2}$ (Figure 2).

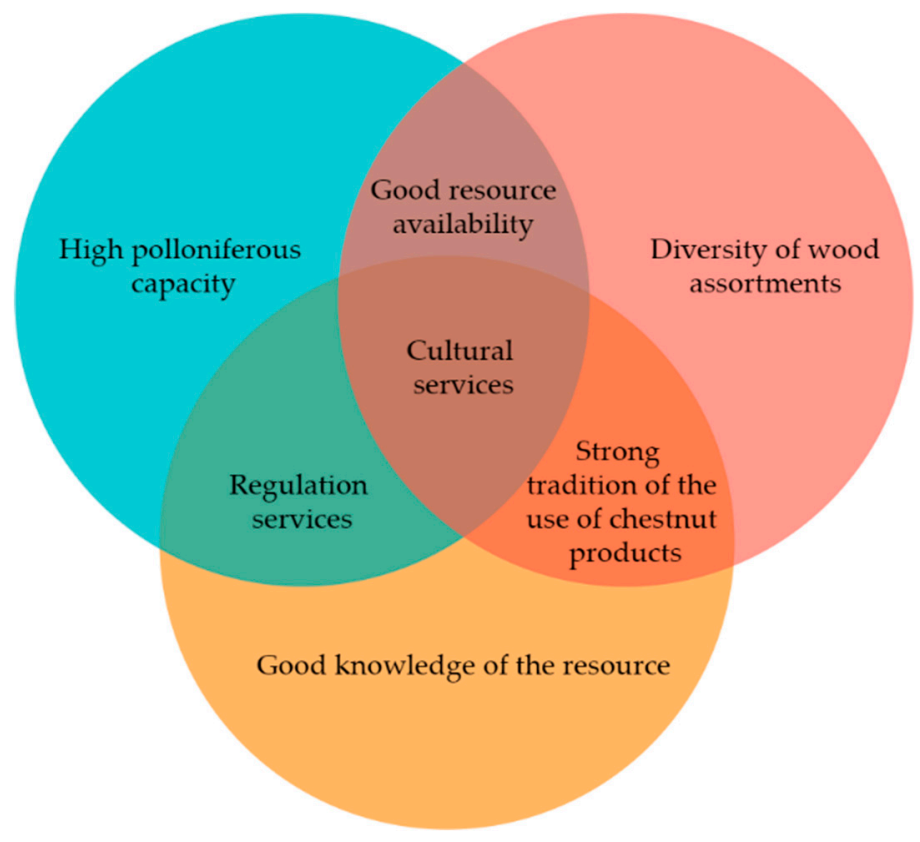

Figure 2. Strengths.

\section{Weaknesses}

The chestnut tree resource, as also supported by the study of Giannini et al. [17], mainly suffers because of the mountain context in which it is located, with all the resulting infrastructural deficiencies and objective difficulties. Moreover, since the post-war period, as stated in the 'National Report on the State of Forests and the Forestry Sector' [39], due to the depopulation of mountainous areas and the lack of economic incentives, there has been an abandonment of management, and only $18 \%$ of the national forest area has a management plan in force. In addition to these aspects, there is strong land 
fragmentation, with more than $70 \%$ of chestnut forests falling into private, small-scale ownership, and a limited associationism of the owners themselves, making it difficult to achieve scale economies.

Another weakness is the scarce information on resources and enterprises, as also stated by Gasparini and Tabacchi [40], with partial and outdated information making it difficult to plan appropriate policy actions in a context of limited resources. Since 2017, the activities related to the survey phase to determine and update the characteristics of forest areas have started, but data are not yet available [41].

Among the intrinsic weaknesses, the propensity of wood defects is also reported, such as ring shake and susceptibility to pathogens and phytophagous, such as chestnut gall wasp and ink disease. These defects, whose impact, as confirmed by Battisti et al. [42], depends particularly on the chestnut cultivar considered, the territorial context and the life cycle in which the plant is located, lead to a reduction of the most valuable assortments, often contribute to modest economic results of silvicultural management, with negative consequences for the related business value chain. In fact, forestry enterprises exploiting this resource often present a lower technological level and an aversion to innovation, being linked to traditional uses which are unable to generate the added value needed to address innovative investments, as evidenced by Pierrettori and Venzi [43].

Finally, as reported by Pettenella and Secco [44] there is a general lack of societal recognition and a lack of knowledge of the ecosystem services provided, which do not allow the concrete emergence of a market linked to them, which could motivate and justify the active management (Figure 3).

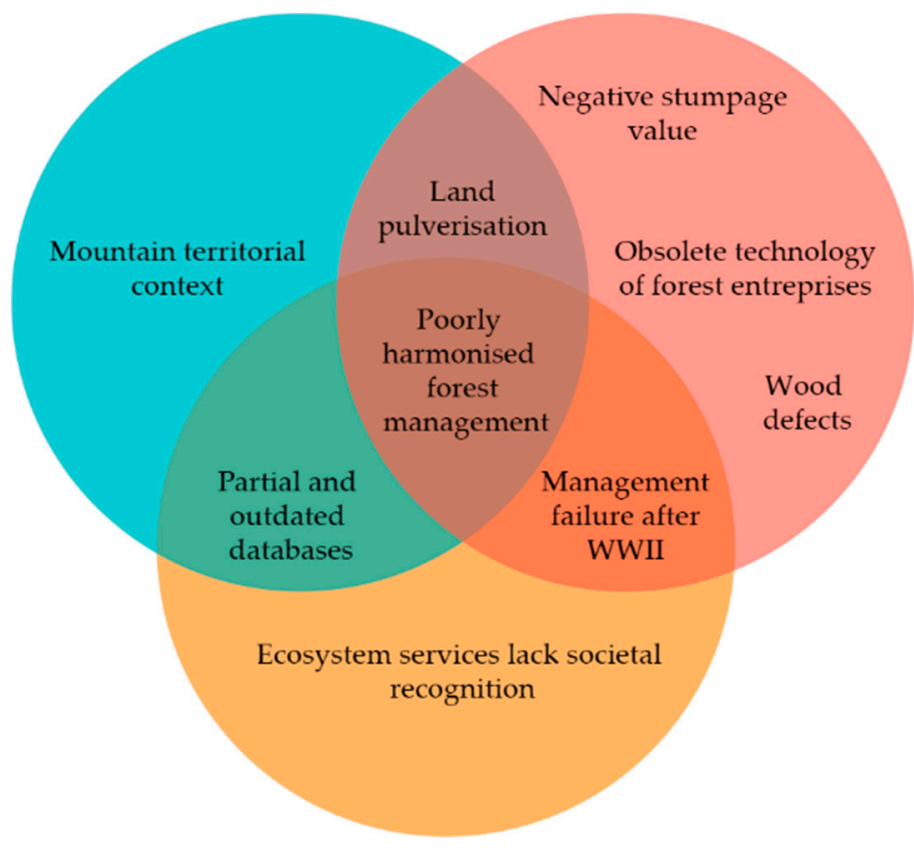

Figure 3. Weaknesses.

\subsubsection{External Factors}

\section{Opportunities}

The opportunities to increase the value of this resource are numerous and potentially able to overcome some of the difficulties described. The first opportunity involves the possibility to create commercial networks, forms of associations between owners or managers and local supply of timber, as Focacci et al. [45] and Cafaggi [45,46] argue, which could resolve the limitations linked to land fragmentation, weak and unbundled supply of chestnut, also ensuring the diversification of chestnut products. 
Such tools, owing to the consolidated know-how of the resource by primary and secondary processing enterprises, could encourage the creation of local and regional supply chains of quality products.

As argued by Di Salvatore and Corona [47], this value chain could also encourage the return of agricultural and forestry entrepreneurs to mountainous areas, in consideration of the generational changes observed in recent years in these sectors, with positive spillover on the development and the recovery of abandoned or underpopulated areas.

In line with the research by the Institute for Wood Plants and Environment (IPLA), the University of Turin (UNITO) and the National Union of Mountain Municipalities, Communities and Authorities (UNCEM) [48], the creation of more structured supply-side markets could be supported by a quality brand, attesting that silvicultural treatments comply with sustainable management standards (according to forest certification schemes), associated with supply chain certification processes, such as Forest Stewardship Council (FSC) and Programme for Endorsement of Forest Certification schemes (PEFC), which could increase regional or national identity. The opportunities related to forest certification are multiple and linked to the three pillars of sustainability. These range from the maintenance and development of forest resources with a focus on the healthiness of ecosystems, to the promotion of the productive functions of forests as well as the ecosystem services and promoting public participation and inclusion.

A further aspect to encourage the management of the resource, by owners or managers, is related to the payment for ecosystem services (PES), as confirmed by Pettenella and Secco [49]. PES are contractual forms, on a voluntary basis, regulated by an economic transaction, in which there are at least two parties, such as the landowner who is committed to providing an ecosystem service, and the beneficiaries of said service, such as tourists or citizens in general [50]. The PES, in addition to the socio-economic aspect, is a win-win approach to environmental sustainability, since an active and profitable management would provide, at the same time, a greater measure of environmental services, as for instance, stability (in terms of resistance and resilience), landscape preservation and increase in biodiversity.

Several studies have been carried out in order to implement such payments in the processes of valorisation of ecosystem services, such as those related to water-related forest services, tourism-related environmental services and the willingness to pay for services produced by regional mountain forests [3,51-53]. However, from the analyses of these studies some common elements emerge, such as the scarcity of data on values at regional scale for Alpine areas, the forest services that have different drivers, dimensions and maturity levels and the civil society that does not yet know the multiple services that an ecosystem is able to provide. There is therefore a need for greater promotion of political activities by public institutions in order to increase the general awareness of forest-related ecosystem services.

Finally, research projects such as those already active nationwide (Table 1), together with targeted public information campaigns and training courses for forest workers and entrepreneurs could further enhance the value of the chestnut tree resource, as asserted by Blanc et al. (Figure 4) [54]. 


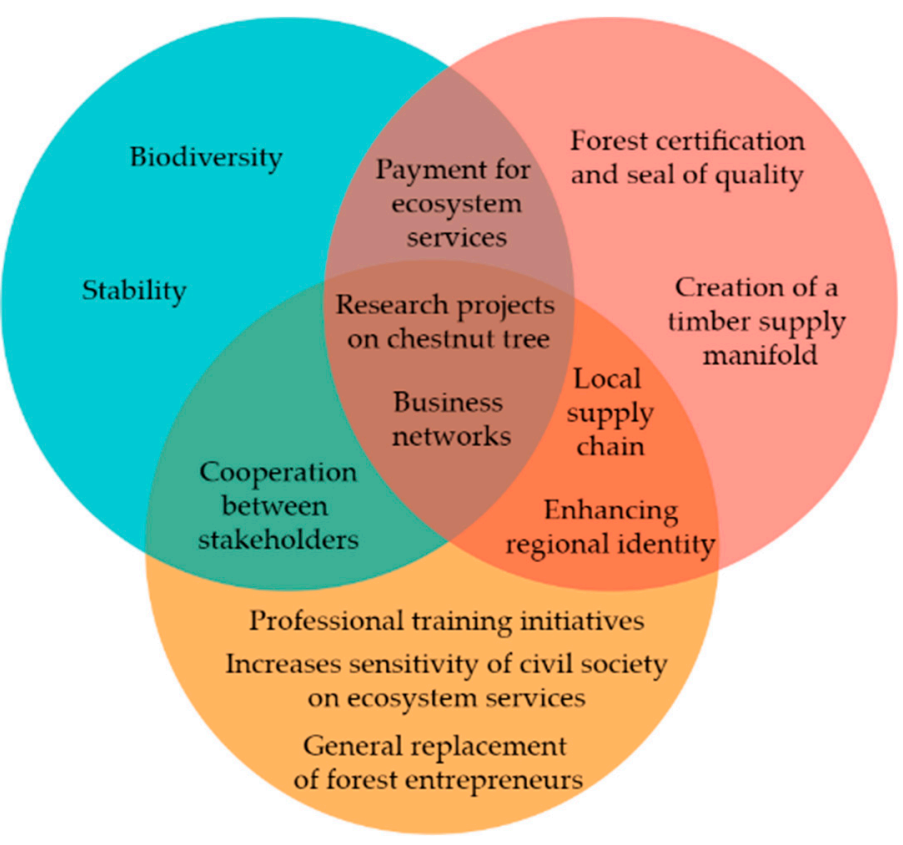

Figure 4. Opportunities.

Table 1. Description of the projects concerning chestnut tree resources in Italy.

\begin{tabular}{|c|c|c|c|}
\hline Project Name & Project Type & Description & Duration \\
\hline Biocastanea & LIFE & $\begin{array}{l}\text { increasing the efficiency of chestnut tree } \\
\text { ecosystems and enhancing its bio-productions }\end{array}$ & \\
\hline CastagnoPiemonte & $\begin{array}{l}\text { RDP 2014-2020 } \\
\text { Measure } 16\end{array}$ & $\begin{array}{c}\text { promotion and enhancement of Piedmontese } \\
\text { chestnut farming }\end{array}$ & $2017-2020$ \\
\hline CastagnoPiù & $\begin{array}{l}\text { RDP 2014-2020 } \\
\text { Measure } 16\end{array}$ & $\begin{array}{l}\text { promotion and valorisation of the Piedmontese } \\
\text { chestnut wood supply chain }\end{array}$ & $2018-2020$ \\
\hline FutureForCoppiceS & LIFE & $\begin{array}{l}\text { improving knowledge for the development of } \\
\text { sustainable coppice management in } \\
\text { southern Europe }\end{array}$ & 2015-2018 \\
\hline MycoRestore & LIFE & $\begin{array}{l}\text { innovative use of mycological resources for } \\
\text { resilient and productive Mediterranean forests } \\
\text { threatened by climate change }\end{array}$ & 2019-2023 \\
\hline $\begin{array}{l}\text { Biodiversamente } \\
\text { Castagno }\end{array}$ & $\begin{array}{l}\text { RDP 2014-2020 } \\
\text { Measure } 16\end{array}$ & $\begin{array}{l}\text { guidelines for the preservation and enhancement } \\
\text { of chestnut biodiversity in Emilia-Romagna }\end{array}$ & $2017-2020$ \\
\hline Lobiocin & MIPAAF & $\begin{array}{l}\text { biological control of the chestnut gall wasp using } \\
\text { the parasitoid Torymus sinensis }\end{array}$ & 2012-2015 \\
\hline Bioinfocast & MIPAAF & fight against the chestnut gall wasp & 2012-2015 \\
\hline Castanea & $\begin{array}{l}\text { Leader II 1994-99 } \\
\text { Leader+ 2000-2006 }\end{array}$ & $\begin{array}{l}\text { carrying out a series of actions aimed at enhancing } \\
\text { and promoting chestnut products, in order to } \\
\text { facilitate their access to the market, and preparing } \\
\text { a response to the need to consider the chestnut } \\
\text { product not only as a final product, but also as a } \\
\text { raw material that must be processed and then } \\
\text { launched on the market, in order to spread the } \\
\text { peculiarities of the product in the areas involved }\end{array}$ & 2004-2008 \\
\hline Sancast & Lazio Region & $\begin{array}{l}\text { introduction of product and process innovations in } \\
\text { the different phases of sorting (qualitative selection } \\
\text { of fruits) and product packaging }\end{array}$ & $2018-2020$ \\
\hline I Castagneti dell'Insubria & Interreg 2007-2013 & valorisation of the sweet chestnut tree & 2010-2014 \\
\hline
\end{tabular}

\section{Threats}

The ongoing climate change and, in the last century, several pathogens, such as ink disease (Phytophthora cambivora (Petri) Buisman and p. cinnamomi Rands.), chestnut blight (Cryphonectria 
parasitica (Murril) Barr.) and the chestnut gall wasp (Dryocosmus kuriphilus Yasumatsu), have led to a sharp decline of the offer and runs the risk of continuing, as observed by different authors [55-57], resulting in the abandonment of chestnut-growing areas, forest aging and subsequent damage to the hydrogeological stability of the slopes [58].

International competition for the production and processing of timber, the strong import of wood and semi-finished products, in addition to the economic crisis in some production sectors, such as construction, have also contributed and still contribute to the decline of the resource.

Some societal aspects are also an obstacle to the development of the chestnut tree. These are, for example, the loss of know-how on woodworking, following the closure of numerous companies or the aforesaid lack of innovation, linked both to the low presence of young entrepreneurs and to the low investment for innovation in this sector, as confirmed by Pierrettori and Venzi [43].

Finally, further threats relate to the insufficient recognition of forest services and the lack of self-supporting capacity of supply chains, unless with public funding, often lacking in this area (Figure 5).

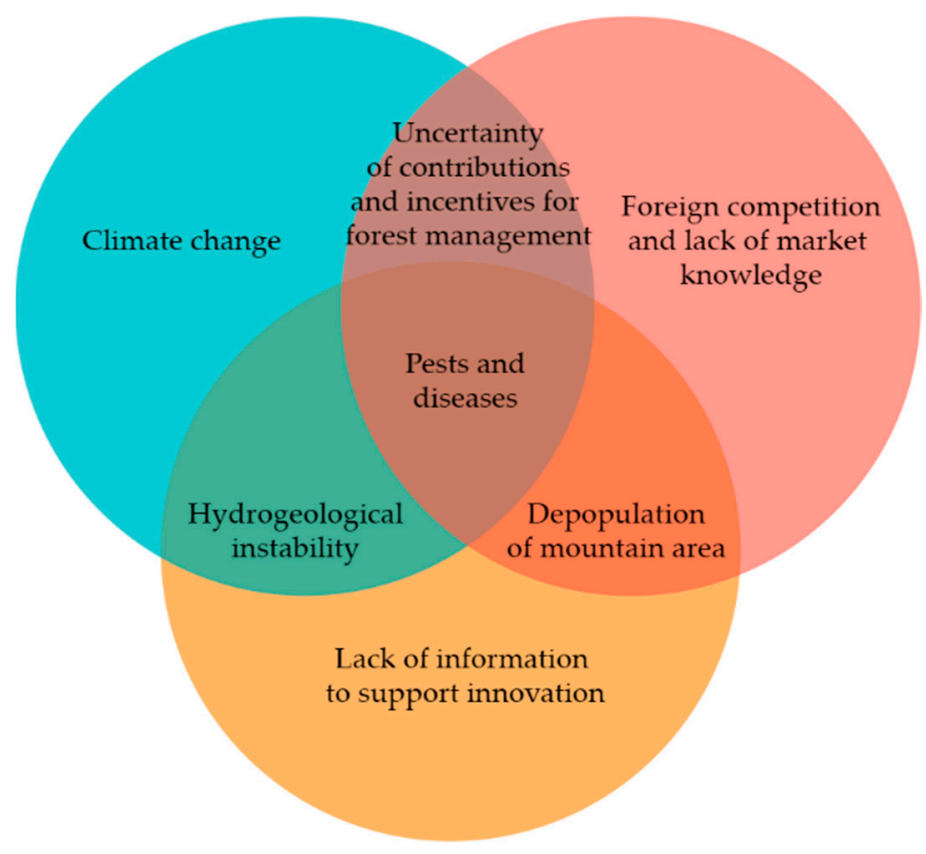

Figure 5. Threats.

\subsection{TOWS Analysis}

The SWOT analysis has made it possible to define different strategies for the valorisation of the chestnut resource in Italy (Table 2). For each of these strategies, different targets have been identified in a structured way, as defined by the UN 2030 Agenda, in the SDGs [24].

Table 2. TOWS matrix.

\begin{tabular}{|c|c|c|c|c|}
\hline & SDG Target & Strengths (S) & SDG Target & Weaknesses (W) \\
\hline Opportunities (O) & $\begin{array}{c}8.4,11 . b, 12.2,15.2 \\
15.4,15 . b\end{array}$ & $\begin{array}{l}\text { 1. Resource-based } \\
\text { S3, S7, O3, O8, O9, } \\
\text { O10, O13 }\end{array}$ & $\begin{array}{c}8.3,8.10,11 . a, 12.8 \\
13.2,13.3\end{array}$ & $\begin{array}{c}\text { 3. Network-based } \\
\text { W1, W2, W4, W5, } \\
\text { O3, O8, O9, O13, } \\
\text { O14, O15 }\end{array}$ \\
\hline Threats (T) & $\begin{array}{c}\text { 8.3, 11.b, } 13.1,13.3 \\
15.9,15 . \mathrm{a}\end{array}$ & $\begin{array}{c}\text { 2. Policy-based } \\
\text { S3, S7, S8, T1, T4, } \\
\text { T5, T6 }\end{array}$ & 11.c, $12.2,15 . a, 15 . b$ & $\begin{array}{l}\text { 4. Market-based } \\
\text { W3, T3, T4, T7, T8 }\end{array}$ \\
\hline
\end{tabular}


Briefly, targets $8.3,8.4,8.10$, are related to the promotion of inclusive and sustainable economic growth, through oriented policies that encourage the formalisation and growth of small and medium enterprises, including access to financial service; targets 11.a, 11.b, 11.c, support links between urban, and rural areas by adopting and implementing integrated policies and plans related to social inclusion, resource efficiency, mitigation and adaptation to climate change; targets $12.2,12.8$, ensure sustainable production and consumption patterns, the sustainable management and efficient use of natural resources; targets 13.1,13.2, 13.3, take actions to combat climate change and its impacts, strengthening resilience and adaptive capacity of forests to climate hazards and natural disasters; targets 15.2, 15.4, 15.9 , 15.a, 15.b, promote the implementation of sustainable management of forests and ensure the conservation of mountain ecosystems, in order to enhance their capacity to provide benefits essential for sustainable development [59].

\subsubsection{S-O Strategies}

The 'resource-based' strategy aims to enhance an optimal availability of chestnut trees on the national territory through local and regional land associations, useful to promote the active management of the resource and the development of the supply chain.

This strategy, therefore, takes into account the management aspects according to the SDG targets, in order to ensure conservation, sustainable management and efficient use of the resource, enhancing not only the wood products but also the ecosystem services provided by the forest.

\subsubsection{S-T Strategies}

The 'policy-based' strategy brings into play, as strong points, the high level of knowledge and the consolidated tradition in the use of the resource, as possible tools to mitigate the effects of climate change on forest resources.

The instrument to achieve the desired results is the adoption of national and local policies and programmes, aimed at increasing the capacity of chestnut forests to withstand biotic and abiotic adversities to aid in the prevention of natural risks. As proposed by the SDG targets, the realisation of these assumptions also passes through awareness raising and information activities towards the various stakeholders involved in decision-making processes and civil society, as well as in the training of operators in the sector.

\subsubsection{W-O Strategies}

The 'network-based' strategy aims to overcome weaknesses such as land pulverisation, poor forest management planning and the widespread technological deficit of forest enterprises.

The opportunities for the valorisation lie in several suggestions: (i) The creation of business networks or other types of cooperation between stakeholders, such as the establishment of local chestnut wood supply gatherers. These operators could organise wood supply basins, ensuring appropriate volumes of raw material for the processing industry; (ii) the development of supply chains from local to regional scale; (iii) the establishment of a quality brand, useful to certify quality, origin and sustainability of the resource.

In line with the SDG targets, public policies can achieve their objectives through the adoption of instruments capable of stimulating entrepreneurship, creativity and innovation, as well as through easily accessible forms of financing for operators.

\subsubsection{W-T Strategies}

The 'market-based' strategy aims to address known resource-related weaknesses, such as wood defects, and threats, such as the lack of innovation of companies operating along the supply chain, in addition to strong foreign competition. 
In accordance with Paletto et al. [60], in order to achieve these prerequisites, it is necessary to create a niche market and introduce advanced technological innovation for primary and secondary processing enterprises that trade the chestnut tree.

Moreover, as defined by the SDG targets, overcoming the limits to the growth of the sector lies in the promotion of entrepreneurial skills. In particular, as stated by Pezzi [38], there is strong know-how in the creation of unique products with high added value, such as those intended for design, or the use of local raw materials for the construction of sustainable buildings.

In view of the implementation of the forthcoming Rural Development Programme, which has a duration of 7 years, the strategy defined as 'resource-based' can be applied in the immediate future, since it only concerns the management aspect. The remaining 'policy-based', 'network-based' and 'market-based' strategies require a longer period for accomplishment, during the phase of the emergence of local and regional associations, in addition to the implementation of plans and programmes.

Finally, in line with several studies concerning the Italian forestry sector [23,61-63], the strategies we defined highlighted the need for forest planning at different levels (e.g., local, regional and national), with the aim of enhancing all forest functions, with a view to sustainability.

Another point in common with the studies mentioned above concerns the consideration that political commitments alone are ineffective in achieving and implementing innovative governance aimed at improving collaboration between the various figures in the forestry sector. The same can be said for the implementation and support of associations and networks of companies [33]. From our point of view, all these aspects are particularly important and essential for sustainable development and the enhancement of the chestnut resource.

\section{Conclusions}

Today's environmental, social and economic threats, such as disease, the abandonment of mountain areas and the loss of craftsmanship roles, in addition to strong international competition and falling demand in the timber sector, have led to the progressive decline of the chestnut tree resource. These phenomena have left large areas abandoned, generating consequent hydrogeological and slope instability.

In this context, the objective of this study was to identify the strengths and opportunities for growth and development of the chestnut wood resource, also taking into account the obstacles posed by the weaknesses and threats, to develop strategies aimed at its enhancement.

The results of our study suggest several strategies capable of combining, in compliance with the UN 2030 Agenda SDGs, different aspects of sustainability. From an environmental point of view, the active management of chestnut forests and the development of a value chain can guarantee sustainable production and resource management processes. From an economic point of view, the technological and process innovation of resource transformation companies could enable them to face global markets in a more competitive way. In addition, the creation of associations, local timber supply gatherers and the development of quality, albeit small-scale, craft activities for the creation of high value-added products could together generate a strong economic and social engine for the revival of the sector.

The commitment of the private sector to the reorganisation of the supply chain, as demonstrated in numerous studies, must also be accompanied by coherent public policy action. This is essential for the adoption of plans, programmes and actions consistent with SDGs, ensuring their prioritisation and implementation. In fact, without the involvement of all actors and the involvement of civil society, these good intentions, even with adequate forms of financing, would remain pledges.

It is important, in this respect, to focus on medium and long-term policy actions. Owing to the strong links of the chestnut tree with the often mountainous and disadvantaged territory, and owing to the great potential of its production, which can generate articulated and sustainable supply chains, the policies for the enhancement of the chestnut tree take on a value that goes beyond national borders. They can be part of a modern vision of the solidarity economy, understood as an economy of 
networks and relations between operators in disadvantaged territories. The success of the chestnut tree cultivation recovery and the valorisation of its supply chains must be based on political actions for the sharing of knowledge and traditions in a modern key, seeking on the one hand a greater efficiency of production processes and markets, and on the other hand, the involvement of the economic operators of the territory, through targeted and bottom-up policies, typical of the rural development approach. The creation of networks, which integrate different sectors and heterogeneous territorial realities, allows the creation of new benefits, based on the richness inherent in local specificities and diversity, where greater diversity means greater strength of the network itself, of its texture, of the quality of the links between the components. All these establish virtuous processes of structural consolidation.

For these reasons, our goal for the future will be to analyse in detail the role of the stakeholders involved in the political process and in the chestnut tree supply chain, examining in greater depth the results of this study and providing evaluation guidelines to support decision-making and strategic processes on the chestnut resource.

Author Contributions: Conceptualisation, S.B. (Stefano Bruzzese), S.B. (Simone Blanc) and F.B.; methodology, S.B. (Stefano Bruzzese), and S.B. (Simone Blanc); validation, S.B. (Simone Blanc) and F.B.; formal analysis, S.B. (Stefano Bruzzese); investigation, S.B. (Stefano Bruzzese); writing-original draft preparation, S.B. (Stefano Bruzzese) and S.B. (Simone Blanc); writing—review and editing, S.B. (Stefano Bruzzese), S.B. (Simone Blanc) and F.B.; supervision, F.B.; project administration, F.B.; funding acquisition, F.B. All authors have read and agreed to the published version of the manuscript.

Funding: The research: provided for by measure 16 of the Rural Development Programme 2014-2020, was funded by the Piedmont Region, within the research project CastagnoPiù (operation 16.2.1).

Conflicts of Interest: The authors declare no conflict of interest.

\section{References}

1. Birdsey, R.; Pan, Y. Trends in management of the world's forests and impacts on carbon stocks. For. Ecol. Manag. 2015, 355, 83-90. [CrossRef]

2. Bürgi, M. A case study of forest change in the Swiss lowlands. Landsc. Ecol. 1999, 14, 567-576. [CrossRef]

3. Jarský, V. Alternative financing options for the forestry sector-Results of the analysis among academics. Zpravy Lesn. Vyzk. 2017, 62, 127-134.

4. García-Ruiz, J.M.; Lana-Renault, N. Hydrological and erosive consequences of farmland abandonment in Europe, with special reference to the Mediterranean region-A review. Agric. Ecosyst. Environ. 2011, 140, 317-338. [CrossRef]

5. Lingua, F.; Mosso, A.; Brun, F.; Blanc, S. A Survey of Innovative Training Preferences Among Italian Loggers. Small-Scale For. 2019, 18, 21-38. [CrossRef]

6. Tsioras, P.A. Perspectives of the forest workers in Greece. IForest 2010, 3, 118-123. [CrossRef]

7. Penttinen, M.; Rummukainen, A.; Mikkola, J. Profitability, Liquidity and Solvency of Wood Harvesting Contractors in Finland. Small-scale For. 2011, 10, 211-229. [CrossRef]

8. Gløersen, E.; Price, M.; Aalbu, H.; Stucki, E.; Roque, O.; Schuler, M.; Perlik, M. Mountain Areas in Europe: Analysis of Mountain Areas in EU Member States, Acceding and Other European Countries; Nordregio: Stockholm, Sweden, 2004.

9. Conedera, M.; Tinner, W.; Krebs, P.; de Rigo, D.; Caudullo, G. Castanea sativa in Europe: Distribution, habitat, usage and threats. In European Atlas of Forest Tree Species; San-Miguel-Ayanz, J., de Rigo, D., Caudullo, G., Houston Durrant, T., Mauri, A., Eds.; Publication Office of the European Union: Luxembourg, 2016; pp. 78-79, ISBN 9789279367403.

10. Manetti, M.; Becagli, C.; Carbone, F.; Corona, P.; Tessa, G.; Romano, R.; Pelleri, F. Guidelines for the Silviculture of Chestnut Coppices; Italian Rural Network: Roma, Italy, 2017. (In Italian)

11. Tabacchi, G.; De Natale, F.; Di Cosmo, L.; Floris, A.; Gagliano, C.; Gasparini, P.; Genchi, L.; Scrinzi, G.; Tosi, V. National Inventory of Forests and Forest Carbon Reservoirs. Surface Area Estimates 2005-Part One; CRA-ISAFA: Trento, Italy, 2007. (In Italian)

12. Conedera, M.; Krebs, P.; Tinner, W.; Pradella, M.; Torriani, D. The cultivation of Castanea sativa (Mill.) in Europe, from its origin to its diffusion on a continental scale. Veg. Hist. Archaeobot. 2004, 13, 161-179. [CrossRef] 
13. Gabrielli, A. The civilization of the chestnut tree. Monti e boschi 1994, 65, 3. (In Italian)

14. Mariotti, B.; Maltoni, A.; Maresi, G. Tradition, Innovation and Sustainability: A Silviculture for the Fruit Chestnut Tree; III Congresso Nazionale Selvicoltura: Messina, Italy, 2009; pp. 851-857. (In Italian)

15. Bentley, J. Economic and Ecological Approaches to Land Fragmentation: In Defense of a Much-Maligned Phenomenon. Annu. Rev. Anthropol. 2003, 16, 31-67. [CrossRef]

16. Camerano, P.; Grieco, C.; Terzuolo, P.G. The Lowland Forests: Knowledge, Conservation and Enhancement; Blu Edizio: Torino, Italy, 2010. (In Italian)

17. Giannini, R.; Maltoni, A.; Mariotti, B.; Paffetti, D.; Tani, A.; Travaglini, D. Enhancement of chestnut stands wood production. L'Italia For. e Mont. 2014, 69, 307-317. [CrossRef]

18. Accastello, C.; Blanc, S.; Mosso, A.; Brun, F. Assessing the timber value: A case study in the Italian Alps. For. Policy Econ. 2018, 93, 36-44. [CrossRef]

19. Cook, E. Agriculture, Forestry and Fishery Statistics. Available online: https:/ec.europa.eu/eurostat/en/web/ products-statistical-books/-/KS-FK-18-001 (accessed on 20 April 2020).

20. Secco, L.; Favero, M.; Masiero, M.; Pettenella, D.M. Failures of political decentralization in promoting network governance in the forest sector: Observations from Italy. Land Use Policy 2017, 62, 79-100. [CrossRef]

21. Motta, R.; Marchetti, M.; Vacchiano, G. Climate and environmental politics needs to be supported by accurate information and communication. What is the role of the scientific community? For. Riv. di Selvic. ed Ecol. For. 2020, 17, 17-22. [CrossRef]

22. Secco, L.; Paletto, A.; Romano, R.; Masiero, M.; Pettenella, D.; Carbone, F.; De Meo, I. Orchestrating forest policy in Italy: Mission impossible? Forests 2018, 9, 468. [CrossRef]

23. Secco, L.; Pettenella, D.; Gatto, P. Forestry governance and collective learning process in Italy: Likelihood or utopia? For. Policy Econ. 2011, 13, 104-112. [CrossRef]

24. Deacon, B. SDGs, Agenda 2030 and the prospects for transformative social policy and social development. J. Int. Comp. Soc. Policy 2016, 32, 1-4. [CrossRef]

25. Baudino, C.; Giuggioli, N.R.; Briano, R.; Massaglia, S.; Peano, C. Integrated methodologies (SWOT, TOWS, LCA) for improving production chains and environmental sustainability of kiwifruit and baby kiwi in Italy. Sustain. 2017, 9, 1621. [CrossRef]

26. Lozano, M.; Vallés, J. An analysis of the implementation of an environmental management system in a local public administration. J. Environ. Manag. 2007, 82, 495-511. [CrossRef]

27. Srivastava, P.K.; Kulshreshtha, K.; Mohanty, C.S.; Pushpangadan, P.; Singh, A. Stakeholder-based SWOT analysis for successful municipal solid waste management in Lucknow, India. Waste Manag. 2005, 25, 531-537. [CrossRef]

28. Doratli, N.; Hoskara, S.O.; Fasli, M. An analytical methodology for revitalization strategies in historic urban quarters: A case study of the Walled City of Nicosia, North Cyprus. Cities 2004, 21, 329-348. [CrossRef]

29. Jackson, S.E.; Joshi, A.; Erhardt, N.L. Recent research on team and organizational diversity: SWOT analysis and implications. J. Manag. 2003, 29, 801-830. [CrossRef]

30. Bernroider, E. Factors in SWOT analysis applied to micro, small-to-medium, and large software enterprises: An Austrian study. Eur. Manag. J. 2002, 20, 562-573. [CrossRef]

31. Helms, M.M.; Nixon, J. Exploring SWOT analysis-Where are we now?: A review of academic research from the last decade. J. Strateg. Manag. 2010, 3, 215-251. [CrossRef]

32. Gottfried, O.; De Clercq, D.; Blair, E.; Weng, X.; Wang, C. SWOT-AHP-TOWS analysis of private investment behavior in the Chinese biogas sector. J. Clean. Prod. 2018, 184, 632-647. [CrossRef]

33. Falcone, P.M.; Tani, A.; Tartiu, V.E.; Imbriani, C. Towards a sustainable forest-based bioeconomy in Italy: Findings from a SWOT analysis. For. Policy Econ. 2020, 110. [CrossRef]

34. Rauch, P.; Wolfsmayr, U.J.; Borz, S.A.; Triplat, M.; Krajnc, N.; Kolck, M.; Oberwimmer, R.; Ketikidis, C.; Vasiljevic, A.; Stauder, M.; et al. SWOT analysis and strategy development for forest fuel supply chains in South East Europe. For. Policy Econ. 2015, 61, 87-94. [CrossRef]

35. Blanc, S.; Brun, F.; Mosso, A. Performance analysis of logging enterprises operating in the western italian alps. Qual.-Access to Success 2019, 20, 74-81.

36. Weihrich, H. The TOWS matrix-A tool for situational analysis. Long Range Plan. 1982, 15, 54-66. [CrossRef]

37. Nikolaou, I.E.; Evangelinos, K.I. A SWOT analysis of environmental management practices in Greek Mining and Mineral Industry. Resour. Policy 2010, 35, 226-234. [CrossRef] 
38. Pezzi, G.; Lucchi, E.; Maresi, G.; Ferretti, F.; Viaggi, D.; Frascaroli, F. Abandonment or survival? Understanding the future of Castanea sativa stands in function of local attitude (Northern Apennine, Italy). Land Use Policy 2017, 61, 564-574. [CrossRef]

39. Rete Rurale Nazionale. Report on the State of Forests and the Forestry Sector in Italy; Compagnia delle Foreste: Arezzo, Italy, 2018; ISBN 978-88-98859-34-1. (In Italian)

40. Tabacchi, G.; De Natale, F.; Floris, A.; Gagliano, C.; Gasparini, P.; Scrinzi, G.; Tosi, V. Italian national forest inventory: Methods, state of the project and future developments. In Proceedings of the seventh annual forest inventory and analysis symposium, Portland, ME, USA, 3-6 October 2005; 2017; pp. 55-66.

41. INFC Press Release. Online al the Information about Italian Forests. Available online: https://www.sian.it/ inventarioforestale/ (accessed on 18 May 2020). (In Italian).

42. Battisti, A.; Benvegnù, I.; Colombari, F.; Haack, R.A. Invasion by the chestnut gall wasp in Italy causes significant yield loss in Castanea sativa nut production. Agric. For. Entomol. 2014, 16, 75-79. [CrossRef]

43. Pierrettori, S.; Venzi, L. The Chestnuts "Filiere" in Italy: Values and Developments; European Forest Institute: Joensuu, Finland, 2009; pp. 85-96.

44. Pettenella, D. Marketing perspectives and instruments for chestnut products and services. For. Snow Landsc. Res. 2001, 76, 511-517.

45. Focacci, M.; De Meo, I.; Paletto, A. Relationship between innovation and networks in chestnut value chain: A case study in Italy. J. For. Sci. 2018, 64, 43-51. [CrossRef]

46. Cafaggi, F. Research questions and methodological profiles. In Industrial Policies and Collaboration between Companies in the Tuscan Context; Cafaggi, F., Iamiceli, P., Eds.; Laboratory Project Networks of Enterprises: Labore, Italy, 2012; pp. 35-57. (In Italian)

47. Di Salvatore, L.; Romano, R.; Corona, P. Potential for the development of networks of companies in the forestry sector in internal Italian areas. L'Italia For. e Mont. 2019, 317-336. (In Italian) [CrossRef]

48. IPLA; UNITO; UNCEM Enhancement of the Chestnut Tree Fruit and Wood Supply Chain. Available online: www.uncem.peimonte.it (accessed on 20 April 2020). (In Italian)

49. Pettenella, D.; Vidale, E.; Gatto, P.; Secco, L. Innovative tools for mountain policies: Payments for environmental services. In Di chi sono le Alpi? Appartenenze politiche, economiche e culturali nel mondo alpino contemporaneo; Varotto, M., Castiglioni, B., Eds.; Padova University Press: Padua, Italy, 2013; pp. 117-131. (In Italian)

50. Wunder, S. Revisiting the concept of payments for environmental services. Ecol. Econ. 2015, 117, $234-243$. [CrossRef]

51. Gatto, P.; Vidale, E.; Secco, L.; Pettenella, D. Exploring the willingness to pay for forest ecosystem services by residents of the Veneto region. Bio-Based Appl. Econ. 2014, 3, 21-43. [CrossRef]

52. Pettenella, D.; Vidale, E.; Gatto, P.; Secco, L. Paying for water-related forest services: A survey on Italian payment mechanisms. IForest 2012, 5, 210-215. [CrossRef]

53. Gatto, P.; Pettenella, D.; Secco, L. Payments for forest environmental services: Organisational models and related experiences in Italy. IForest 2009, 2, 133-139. [CrossRef]

54. Blanc, S.; Lingua, F.; Bioglio, L.; Pensa, R.G.; Brun, F.; Mosso, A. Implementing participatory processes in forestry training using social network analysis techniques. Forests 2018, 9, 463. [CrossRef]

55. Müllerová, J.; Hédl, R.; Szabó, P. Coppice abandonment and its implications for species diversity in forest vegetation. For. Ecol. Manag. 2015, 343, 88-100. [CrossRef]

56. Zlatanov, T.; Schleppi, P.; Velichkov, I.; Hinkov, G.; Georgieva, M.; Eggertsson, O.; Zlatanova, M.; Vacik, H. Structural diversity of abandoned chestnut (Castanea sativa Mill.) dominated forests: Implications for forest management. For. Ecol. Manag. 2013, 291, 326-335. [CrossRef]

57. Pereira, M.G.; Caramelo, L.; Gouveia, C.; Gomes-Laranjo, J.; Magalhães, M. Assessment of weather-related risk on chestnut productivity. Nat. Hazards Earth Syst. Sci. 2011, 11, 2729-2739. [CrossRef]

58. Tagliaferri, G.; Lonardo, S. Chestnut Management Practice as Tool for Natural and Cultural Landscaping. In Biocultural Diversity in Europe; Springer Nature: Cham, Switzerland, 2016; Volume 5, pp. 353-367, ISBN 978-3-319-26313-7.

59. United Nations Sustainable Development Goals. 17 Goals to Transform Our World. Available online: https://www.un.org/sustainabledevelopment/ (accessed on 18 May 2020).

60. Paletto, A.; Focacci, M.; De Meo, I. Farmers' opinions on chestnut (Castanea sativa Mill.) supply chain development strategies: A case study in central Italy. For. Syst. 2018, 27. [CrossRef] 
61. Paletto, A.; Giacovelli, G.; Matteucci, G.; Maesano, M.; Pastorella, F.; Turco, R.; Mugnozza, G. Strategies for the promotion of the forest-wood chain in Calabria (southern Italy): The stakeholders' point of view. J. Silvic. For. Ecol. 2017, 14, 34-48. [CrossRef]

62. Maetzke, F.; Cullotta, S. Environmental and Forest Planning in Italy: Conflicts and Opportunities. Agric. Agric. Sci. Procedia 2016, 8, 332-338. [CrossRef]

63. Vizzarri, M.; Tognetti, R.; Marchetti, M. Forest ecosystem services: Issues and challenges for biodiversity, conservation, and management in Italy. Forests 2015, 6, 1810-1838. [CrossRef]

(C) 2020 by the authors. Licensee MDPI, Basel, Switzerland. This article is an open access article distributed under the terms and conditions of the Creative Commons Attribution (CC BY) license (http://creativecommons.org/licenses/by/4.0/). 